\title{
Phylloremediation of Polyaromatic Hydrocarbonic Pollutants Using Phylloshere Bacteria
}

\author{
Undugoda LJS*, Nilmini AHL and Nugara NNRN
}

Department of Biosystems Technology, Faculty of Technology, University of Sri Jayewardenepura, Sri Lanka

*Corresponding author: Undugoda LJS, Department of Biosystems Technology, Faculty of Technology, University of Sri Jayewardenepura, Sri Lanka, Tel: +94112758000; E-mail: lankaundugoda@sjp.ac.Ik

Received: October 27, 2018; Accepted: November 15, 2018; Published: November 23, 2018

Copyright: (c) 2018 Undugoda LJS, et al. This is an open-access article distributed under the terms of the Creative Commons Attribution License, which permits unrestricted use, distribution, and reproduction in any medium, provided the original author and source are credited.

\begin{abstract}
Polyaromatic air pollution is a serious environmental issue in the modern world due to the high carcinogenicity and geno-toxicity of these pollutants to the all-living beings. These pollutant concentrations in the air are being increased day by day due to huge vehicular emissions, oil refining processes and other industrial processes spread among urbanized areas. Gas or particle bounded PAHs in the air deposit on ground level through wet deposition or dry deposition. These pollutants deposition mainly on plants other than many exposing surfaces spread among the earth. Therefore, the plant leaves highly abundant in urban areas rich with these deposited pollutants. All plant leaves are great niches for microorganisms which is called phyllosphere. Phyllosphere of plants consists with many phyllosphere microorganisms belong to different group of bacteria, fungi, algea and protozoa. Among them bacteria are the predominant phyllosphere microorganisms. The phyllosphere bacteria highly abundant in polluted areas have special capability to degrade polyaromatic hydrocarbons. These PAH degrading phyllophere microorganisms can be used to clean the polluted air, this is called phylloremediation. Phylloremediation is an effective bioremediation method which can use to remediate the air, water and soil polluted from the PAH compounds. The aim of this review is to discuss polyaromatic hydrocarbonic air pollution and deposition of these chemicals on phyllosphere. High depositions of PAHs on plant leaves created harsh conditions to the inhabiting bacterial population in this phyllosphere and their ability to degrade PAH compounds are discussed. Then possibilities of usage of phylloremediation to clean the polluted air from the PAH compounds are discussed.
\end{abstract}

Keywords: Phylloremediation; Phyllosphere; Polyaromatic hydrocarbons; Bacteria; Bioremediation

\section{Introduction}

Polyaromatic hydrocarbons are a group of organic compounds composed of two or more fused aromatic rings of complex organic compounds. Currently, more than 100 different PAHs are available in the environment and out of them $17 \mathrm{PAH}$ compounds were informed as the highly risky compounds by ATSDR [1]. Out of them eight PAHs are typically considered as carcinogenic compounds. These are, benzo(a)anthrocene, chrysene, benzo(b)fluoranthene, benzo(k)fluoranthene, dibenzo(a,h)anthracene, indeno(1,2,3cd)pyrene and benzo(g,h,i)perylene [2]. But US EPA announced 16 PAHs as priority pollutants. They are, acenaphthene, acenaphthylene, anthracene, benzo(a)anthrocene, benzo(b)fluoranthene, benzo(k)fluoranthene, benzo(g,h,i)perylene, dibenzo(a,h)anthracene, chrysene, dibenzo(a,h)anthracene, fluoranthene, fluorine, indeno(1,2,3-cd)pyrene, phenanthrene, naphthalene and pyrene. Among them phenanthrene and naphthalene are carcinogenic hazardous compounds which are released in to the air due to vehicular emission and oil refinery processes. The released PAHs into air through these sources come back to earth through the wet and dry deposition methods. Some of these PAHs deposit on plant leaves. Plant leaves are great niches for many microorganisms belong to different groups as bacteria, fungi, algea, protozoa and nematodes. The microbes inhabit plant leaves are called phyllosphere. Bacteria are the predominant microbes in phyllosphere. Deposited PAHs in phyllosphere create a stress conditions to inhabiting bacteria and some of them can adapt to this harsh conditions. As an adaptation they have the capability to degrade PAHs into nontoxic level. This character can be used to remediate the $\mathrm{PAH}$ pollutants in the air, water and soil. This bioremediation concept is called phylloremediation.

\section{Polyaromatic Hydrocarbonic Air Pollution}

PAH compounds are formed as a result of many anthropogenic sources and some of the natural sources [3]. Natural sources of emissions are prairie and forest fires or volcanic eruptions like natural processes which contribute to the PAHs concentration in the atmosphere. Anthropogenic activities such as coal and oil-fired power plants, automobile and furnace exhausts, gasification/liquefaction of fossil fuels, waste incineration, coke and asphalt production, aluminum smelting and gas, vehicular emission and oil flare operations are sources of these PAH compounds into the air [4]. The results of Muendo et al. [5], convinced the air samples collected from traffic areas of Kenya showed higher PAH concentrations and 30\% of collected air samples are consisted with hazardous compounds. According to the results of Edoardo et al. [6], air samples collected from urbanized areas of Europe consisted with highly carcinogenic benzo[a]pyrene in the range of $1-20 \mathrm{ng} / \mathrm{m}^{3}$. Other PAHs, individual concentrations were generally in the range of $1-50 \mathrm{ng} / \mathrm{m}^{3}$ in Europe. Air pollution of urbanized areas is mostly due to vehicular emission and some oil refinery processes. In fact, main source of napthalenes, phenanthrene, fluoranthene, and pyrene like PAHs are diesel engines $[3,7,8]$. Other most of PAHs release in to air as a result of vehicular emission and release gasses from oil refinery processes. The research of Nascimbene et al. [9], which was done using lichens as bio monitors 
around the area of Dolamite in Italy showed PAH concentrations in air are higher along the roadside of this urbanized area other than the rural area far away from this urbanized area. Further, this research revealed phenanthrene, anthracene and pyrene concentrations along roadsides of tested urbanized areas are higher compare to the area away from this road side. Further the results of Blasco et al. [10] indicated phenanthrene is the most abundance PAH pollutant in the air and also other highly prevalence PAHs are fluoranthene, pyrene, naphthalene and benzo(g,h,i)perylene. These 17 PAHs in the environment are highly carcinogenic and genotoxic to the all living beings. Out of these 17 PAHs naphthalene is a highly toxic compound to all the living being. Naphthalene covalently binds to liver, kidney and lung tissue and effect to their function [11]. In addition to that it leads to haemolytic anaemia, nephrotoxicity, dermal and ophthalmological changes. Phenanthrene is also a hazardous PAH which cause photosensitizing of human skin, a mild allergen, potent inhibiting of gap junctional intercellular communication and tumor initiation. Some research indicated the cancer risk of toxicity from acenaphthene, fluranthene and flourene.

\section{Polyaromatic Hydrocarbonic Depositions on Plants}

PAHs can be deposited on plants from contaminated soil or atmosphere. This deposition method depends on chemical and physical properties of the pollutant or the environmental condition [12]. But major PAH deposition is from atmosphere. It can be deposited from wet deposition or dry deposition based on the molecular weight of PAH compound. In fact, the lighter, smaller PAHs tend to deposit into plants through dry gasses deposition and the larger, heavier 5 PAHs are usually in particulate form and can be deposited on to plant surface in wet and dry deposition [13]. The deposited amount on the plant leaves depends on PAH concentration of the air and morphological and chemical characteristics of plant leaf [14]. The samples collected from Highway roadsides of Johor showed higher PAH depositions on plants compare to the rural areas. In fact, orange jasmine leaves, Murraya paniculata (L.) collected from roadsides of Bangkok showed 63.99 to $82.46 \mathrm{mg} / \mathrm{kg}$ concentration of $\mathrm{PAH}$ depositions on the leaves [15]. According to the results of Wang et al. [16], leaf cuticles collected from six tree species from urban Beijing, China, showed $69-\mathrm{mg} / \mathrm{kg}$ amount of PAH on leaves. The results of Undugoda et al. [17] revealed the phyllosphere of Ixora chinensis collected from the urbanized areas of Sri Lanka showed the highest naphthalene (160 ng/g), phenanthrene $(96.1 \mathrm{ng} / \mathrm{g})$, toluene $(85.66 \mathrm{ng} / \mathrm{g})$ and xylene $(54.39 \mathrm{ng} / \mathrm{g})$ concentrations. Moreover the results of Bohme et al. [18], revealed the accumulation of PAH on plant leaf surfaces correlate with the PAH concentrations of ambient air. PAHs exist in the air as gasses or particle bound compounds are reached the plant surfaces by both dry and wet deposition [19]. But depositing amount can be vary based on the plant species, morphological and chemical constitutions [20]. The study of Choi et al. [21], revealed, phenanthrene, anthracene, and pyrene concentrations on deciduous forest in Southern Ontario, Canada, were reduced within and above the forest canopy during bud break in early spring.

\section{Bacteria Inhabit the Phyllosphere of Plants}

To study planktonic species, water samples were collected once in a month between 7.00 am and 10.00 am for six months (February-July 2017) from all the ten (S1-S10) sampling stations by scooping water at the depth of $15-30 \mathrm{~cm}$ below the water surface and filtered through a plankton net with pore size of $64 \mu \mathrm{m}$, transferred into $100 \mathrm{ml}$ glass bottles and fixed with acidic Lugol's Iodine solution before transporting to laboratory for identification of species and water analysis. To study planktonic species /diatoms, one drop or $0.2 \mathrm{ml}$ of water from each sample was placed in an Utermohl sampling chamber and kept at least for three hours to get settled [2]. Species were studied using a Zeiss Axioinvert 35 inverted microscope at 40X magnification, identified and confirmed with taxonomic keys [22].

\section{PAH Degrading Bacteria in Phyllosphere}

Natural phyllosphere bacteria are able to degrade many air pollutants such as phenanthrene, naphthalene like PAHs and toluene, phenol, ethylbenzene, xylene, like monoaromatic hydrocarbons $[22,23]$. In fact, microorganisms isolated from the spruce needles showed trichloroacetic acid degradation ability [24]. The results of Charoenchang et al. [25] revealed, the bacterial consortium inhabiting on the dried rain tree leaves have the ability to degrade phenanthrene, fluoranthene and pyrene. The leaf samples collected from four plant species (Ixora chinensis, Evertamia dervaticata, Hibiscus rosa-sinensis and Amaranthus cruentus) which were highly abundant in the urbanized areas of Sri Lanka had phenanthrene and naphthalene degrading bacterial species, Alcaligenes faecalis, Alcaligenes sp.11SO, Bacillus cereus, Bacillus methylotrophicus, Serratia marcescens, Alcaligenes sp. BC and Alcaligenes sp. [26]. The results of Waight et al. [14] revealed, the bacterial species Sphingomonas, Pseudomonas, Microbacterium, Rhizobium, and Deinococcus spp. which were isolated from six plant species Wrightia religiosa Benth. ex Kurz, Pereskia grandiflora Haw., Hibiscus rosa-sinensis L., Excoecaria cochinchinensis Lour. var. cochinchinensis, Ixora sp., and Hymenocallis littoralis Salisb in urbanized areas of Bankok showed higher phenanthrene degradation ability. The results of Ma et al. [27] showed various species belongs to Pseudomonas were able to degrade $\mathrm{PAH}$ and the results of Daane et al. [28,29] showed genus Micobacterium had PAH degradation ability. Furthermore, Rizobium sp. isolated in the research of Andreoni et al. [30] showed PAH degradation ability. The results of Chang et al. [31] showed the isolated bacterial genus Deinococcus had PAH-degrading activity, this was the only one research which recorded this species for PAH degradation.

\section{Usage of Phyllosphere PAH Degraders for Bioremediation}

Over the past decade, the trend of bioremediation has been increased to clean the environment from PAH and other pollutants. The results of Wilson et al. [32], showed many natural soil bacterial species were able to degrade PAH pollutants efficiently. In fact, $\mathrm{PAH}$ and phenol-utilizing microorganisms were used to remediate the soil from a creosote plant containing PAHs and phenols using an ex situ land treatment process [33]. This showed $82-97 \%$ degradation of lower PAHs (and up to 35\% degradation of higher PAHs). Bioremediation of oil spills on the shoreline on Delaware Bay was carried out using different types of microorganisms inhabit the soil samples spread around this site [34]. Like these researches initially soil with PAH degrading microorganisms were used to clean the PAH contaminated sites. Then instead of usage of natural soil samples with microorganisms, microorganisms were isolated from the soil and then these isolated bacterial and fungal species were separately added to the contaminated site as bioremediators.

In modern world, PAH degrading bacterial species isolated from contaminated soil are used to clean the PAH contaminated soil sites. In 
fact, the results of Straube et al. [35] revealed, Pseudomonas aeruginosa strain 64 is able to degrade PAHs in the contaminated soil and sediments. One year after the treatment, $86 \%$ of PAH in the site is removed by this inoculum. According to the research of Guerin et al. [33], effective microbes in the compost also can be used to remove PAHs in some contaminated sites. As well as, the results of Sasek et al. [36] revealed PAH contaminated soil exist around a gas plant is remediated using compost inoculum. Moreover, studies of Singleton et al. [37], showed the removal of PAHs present in contaminated soil using the associated bacterial communities who cultured in a bioreactors as semi-continuous or fed batch cultures. Then they showed 76\% PAH degrading ability.

Current trend is on use of phyllosphere microorganisms to remediate most of the deposited air pollutants. The results of many modern research revealed, the microorganisms inhabit the phyllophere of plant leaves spread around the contaminated site were able to degrade PAHs deposit on these leaves and these microorganisms can be used as bioremediators. As this we can use phyllosphere PAH degrading bacteria and fungi to remediate the PAH contaminants in the environment this process is called phylloremediation [38-45]. In fact, the results of Forczek et al. [24], revealed, microorganisms colonizing in the spruce needles are responsible for the decrease of trichloroacetic acid in air samples. Moreover, the results of Darlington et al. [22], showed natural phyllosphere bacteria are able to degrade monoaromatic hydrocarbons such as toluene, phenol, ethylbenzene, and xylene. Microbial consortium isolated from dried rain tree leaves in Thailand, were able to degrade phenanthrene, fluoranthene and pyrene very well [25].

The planting ornamental plants with high number of $\mathrm{PAH}-$ degrading bacteria in urban areas is a good solution for the environmental PAH pollution. As well as developing biofilters from plant leaves and phyllosphere bacteria for improving indoor air quality. This knowledge is valuable for the development of ecological strategies for minimizing outdoor PAHs and improving air quality in urban areas [46-52].

\section{Conclusions}

Phylloremediation is an ecofriendly concept for the air pollution. This concept can easily use for the PAH pollutants which are highly carcinogenic and genotoxic for all the living beings. Phyllosphere of many plants inhabit the polluted areas highly abundant with $\mathrm{PAH}$ degrading bacterial and fungal species. Due to these enriched PAH degraders, we can grow these plants with $\mathrm{PAH}$ degrading microorganisms indoor and outdoor to remediate pollutants in air after deposition on to these plant leaves. And also by isolating these PAH degrading microbes, biofilters can be introduced to clean the polluted air. All in all phylloremediation is a highly suit bioremediation concept for the air pollution.

\section{References}

1. Agency for Toxic Substances and Disease Registry (ATSDR) (2000) Toxicological profile for Toluene. US Department of Health and Human Services, Public Health Service, Atlanta, GA, USA.

2. Menzie CA, Potocki BB, Santodonato J (1992) Exposure to carcinogenic PAHs in the environment. Environmental Science \& Technology 26: 1278-1284.

3. Harrison RM, Smith DJ, Luhana L (1996) Source apportionment of atmospheric polycyclic aromatic hydrocarbons collected from an urban location in Birmingham, UK. Environmental Science \& Technology 30: 825-832.

4. Mackay D, Hickie B (2000) Mass balance model of source apportionment, transport and fate of PAHs in Lac Saint Louis, Quebec. Chemosphere 41: 681-692.

5. Muendo M, Hanai Y, Kameda Y, Masunaga S (2006) Polycyclic aromatic hydrocarbons in urban air: concentration levels, patterns, and source analysis in Nairobi, Kenya. Environmental Forensics 7: 147-157.

6. Menichini E (1992) Urban air pollution by polycyclic aromatic hydrocarbons: levels and sources of variability. Science of the Total Environment 116: 109-135.

7. USEPA (1993) Compilation of Air Pollutant Emission Factors-AP42Supplement F, 3.3-3.4., Environmental Protection Agency, Washington, DC, USA.

8. Cooper DA, Peterson K, Simpson D (1996) Hydrocarbon, PAH and PCB emissions from ferries: a case study in the Skagerak-Kattegatt-Öresund region. Atmospheric Environment 30: 2463-2473.

9. Nascimbene J, Tretiach M, Corana F, Schiavo FL, Kodnik D, et al. (2014) Patterns of traffic polycyclic aromatic hydrocarbon pollution in mountain areas can be revealed by lichen biomonitoring: A case study in the Dolomites (Eastern Italian Alps). Science of the Total Environment 475: 90-96.

10. Blasco M, Domeño C, Nerín C (2006) Use of lichens as pollution biomonitors in remote areas: comparison of PAHs extracted from lichens and atmospheric particles sampled in and around the Somport tunnel (Pyrenees). Environmental Science \& Technology 40: 6384-6391.

11. Falahatpisheh MH, Donnelly KC, Ramos KS (2001) Antagonistic interactions among nephrotoxic polycyclic aromatic hydrocarbons. Journal of Toxicology and Environmental Health Part A 62: 543-560.

12. Simonich SL, Hites RA (1995) Organic pollutant accumulation in vegetation. Environmental Science \& Technology 29: 2905-2914.

13. Howsam M, Jones KC, Ineson P (2000) PAHs associated with the leaves of three deciduous tree species. I-concentrations and profiles. Environmental Pollution 108: 413-424.

14. Waight K, Pinyakong O, Luepromchai E (2007) Degradation of phenanthrene on plant leaves by phyllosphere bacteria. The Journal of General and Applied Microbiology 53: 265-272.

15. Karnchanasest B, Satayavibul A (2005) Orange jasmine leaves as an indicator of atmospheric polycyclic aromatic hydrocarbons. Songklanakarin J Sci Technol 27: 877-888.

16. Wang YQ, Tao S, Jiao XC, Coveney RM, Wu SP, et al. (2008) Polycyclic aromatic hydrocarbons in leaf cuticles and inner tissues of six species of trees in urban Beijing. Environmental Pollution 151: 158-164.

17. Undugoda LJ, Kannangara S, Sirisena DM (2016) Genetic Basis of Naphthalene and Phenanthrene Degradation by Phyllosphere Bacterial Strains Alcaligenes faecalis and Alcaligenes sp. 11SO. J Bioremed Biodeg $7: 333$.

18. Böhme F, Welsch-Pausch K, McLachlan MS (1999) Uptake of airborne semivolatile organic compounds in agricultural plants: field measurements of interspecies variability. Environmental Science \& Technology 33: 1805-1813.

19. Bakker MI, Tolls J, Kolloffel C (2001) Deposition of atmospheric semivolatile organic compounds to vegetation. The Journal of Environmental Science 24: 286-298.

20. Librando V, Perrini G, Tomasello M (2002) Biomonitoring of atmospheric PAHs by evergreen plants: correlations and applicability. Polycyclic Aromatic Compounds 22: 549-559.

21. Choi SD, Staebler RM, Li H, Su Y, Gevao B, et al. (2008) Depletion of gaseous polycyclic aromatic hydrocarbons by a forest canopy. Atmospheric Chemistry and Physics 8: 4105-4113.

22. Darlington AB, Dat JF, Dixon MA (2001) The biofiltration of indoor air: air flux and temperature influences the removal of toluene, ethylbenzene, and xylene. Environmental Science \& Technology 35: 240-246. 
23. De Kempeneer L, Sercu B, Vanbrabant W, Van Langenhove H, Verstraete W (2004) Bioaugmentation of the phyllosphere for the removal of toluene from indoor air. Applied Microbiology and Biotechnology 64: 284-248.

24. Forczek ST, Matucha M, Uhlírová $H$, Albrechtová J, Fuksová $K$, et al. (2001) Biodegradation of trichloroacetic acid in Norway spruce/soil system. Biologia Plantarum 44: 317-320.

25. Charoenchang N, Pinphanichakarn P, Pattaragulwanit K, Thaniyavarn S, Juntongjin K (2003) Utilization of agricultural materials to enhance microbial degradation of polycyclic aromatic hydrocarbons in soil. J Sci Res 28: 1-3.

26. Undugoda LJ, Kannangara S, Sirisena DM (2016) Aromatic Hydrocarbon Degrading Fungi Inhabiting the Phyllosphere of Ornamental Plants on Roadsides of Urban Areas in Sri Lanka. J Bioremed Biodeg 7: 328.

27. Ma Y, Wang L, Shao Z (2006) Pseudomonas, the dominant polycyclic aromatic hydrocarbon-degrading bacteria isolated from Antarctic soils and the role of large plasmids in horizontal gene transfer. Environmental Microbiology 8: 455-465.

28. Daane LL, Harjono I, Zylstra GJ, Häggblom MM (2001) Isolation and characterization of polycyclic aromatic hydrocarbon-degrading bacteria associated with the rhizosphere of salt marsh plants. Applied and Environmental Microbiology 67: 2683-2691.

29. Gauthier E, Deziel E, Villemur R, Juteau P, Lepine F, et al. (2003) Initial characterization of new bacteria degrading high-molecular weight polycyclic aromatic hydrocarbons isolated from a 2 -year enrichment in a two-liquid-phase culture system. Journal of Applied Microbiology 94: 301-311.

30. Andreoni V, Cavalca L, Rao MA, Nocerino G, Bernasconi S, et al. (2004) Bacterial communities and enzyme activities of PAHs polluted soils. Chemosphere 57: 401-412.

31. Chang YT, Lee JF, Chao HP, Liao WL (2006) Bacterial community changes with $\mathrm{N}^{\prime}-\mathrm{N}^{\prime}$ dimethylforamide (DMF) additives during polycyclic aromatic hydrocarbons (PAH) biodegardation. Environmental Technology 27: 1-4.

32. Wilson SC, Jones KC (1993) Bioremediation of soil contaminated with polynuclear aromatic hydrocarbons (PAHs): A review. Environmental Pollution 81: 229-249.

33. Guerin TF (1999) Bioremediation of phenols and polycyclic aromatic hydrocarbons in creosote contaminated soil using ex-situ landtreatment. Journal of Hazardous Materials 65: 305-315.

34. Venosa AD, Suidan MT, Wrenn BA, Strohmeier KL, Haines JR, et al (1996) Bioremediation of an experimental oil spill on the shoreline of Delaware Bay. Environmental Science \& Technology 30: 1764-1775.

35. Straube WL, Nestler CC, Hansen LD, Ringleberg D, Pritchard PH, et al. (2003) Remediation of polyaromatic hydrocarbons (PAHs) through landfarming with biostimulation and bioaugmentation. Acta Biotechnologica 23: 179-196.

36. Sasek S (2003) Why mycoremediations have not yet come to practice. In: The utilization of bioremediation to reduce soil contamination: Problems and solutions. Kluwer Academic Publishers, pp: 247-276.
37. Singleton DR, Richardson SD, Aitken MD (2008) Effects of enrichment with phthalate on polycyclic aromatic hydrocarbon biodegradation in contaminated soil. Biodegradation 19: 577-587.

38. Sandhu A, Halverson LJ, Beattie GA (2009) Identification and genetic characterization of phenol-degrading bacteria from leaf microbial communities. Microb Ecol 57: 276-285.

39. Andrews JH (1996) Phyllosphere ecology, past, present and future. Aerial Plant Surface Microbiology. Platinum Press, New York, USA, pp: 285-294.

40. Carroll FE (1977) Preliminary studies on the incidence of needle endophytes in some European conifers. Sydowia 29: 87-103.

41. Ercolani GL (1991) Distribution of epiphytic bacteria on olive leaves and the influence of leaf age and sampling time. Microbial Ecology 21: 35-48.

42. Hirano SS, Upper CD (1991) Bacterial community dynamics. In: Microbial ecology of leaves. New York, USA, pp: 271-294.

43. Kowalchuk GA, Yergeau E, Leveau JH, Sessitsch A, Bailey M, et al. (2010) Plant-associated microbial communities. Environmental Molecular Microbiology, pp: 131-148.

44. Lambais MR, Crowley DE, Cury JC, Büll RC, Rodrigues RR (2006) Bacterial diversity in tree canopies of the Atlantic forest. Science 312: 1917.

45. Lindow SE, Brandl MT (2003) Microbiology of the phyllosphere. Appl Environ Microbiol 69: 1875-1883.

46. Mastrangelo G, Fadda E, Marzia V (1996) Polycyclic aromatic hydrocarbons and cancer in man. Environmental Health Perspectives 104: 1166-11670.

47. Morris CE, Kinkel LL (2002). Fifty years of phyllosphere microbiology: significant contribution to research in related fields. Phyllosphere Microbiology. APS Press, Minnesota, pp: 365-375.

48. Petrini O (1991) Fungal endophytes of tree leaves. In: Andrews JH, Hirano SS (eds.), Microbial Ecology of Leaves, Springer-Verlag, New York, USA, pp: 179-190.

49. Riederer M (2006) Biology of the plant cuticle. Blackwell Publishing, Oxford, UK.

50. Thompson IP, Bailey MJ, Fenlon JS, Fermor TR, Lilley AK, et al. (1993) Quantitative and qualitative seasonal changes in the microbial community from the phyllosphere of sugar beet (Beta vulgaris). Plant and Soil 150: 177-191.

51. Whipps JM, Hand P, Pink D, Bending GD (2008) Phyllosphere microbiology with special reference to diversity and plant genotype. J Appl Microbiol 105: 1744-1755.

52. Yadav RKP, Karamanoli K, Vokou D (2005) Bacterial colonization of the phyllosphere of Mediterranean perennial species as influenced by leaf structural and chemical features. Microbial Ecology 50: 185-196. 